\title{
Evaluation on Regional Scientific and Technological Innovation Capacity Based on Principal Component Analysis
}

\author{
Xing $\mathrm{Li}$ \\ LongDong University, No. 45, Lanzhou Rd., Xifeng \\ District, Qingyang City 745000, Gansu, China \\ Asia University No. 500, Liufeng Rd., Wufeng, Taichung \\ City 41354, Taiwan \\ E-mail: leebj@189.cn
}

\author{
James K.C. Chen \\ Asia University No. 500, Liufeng Rd., Wufeng, Taichung \\ City 41354, Taiwan \\ e-mail:kcchen@asia.edu.tw
}

\begin{abstract}
Through establishing the indicator system that reflects the regional scientific and technological innovation capacity, this paper applies the Principal Component Analysis and Cluster Analysis Method to make empirical analysis and comparative analysis on regional scientific and technological innovation capacity of 30 provinces, cities and districts within China Mainland, and concludes the comprehensive ranking of all regions' scientific and technological innovation capacity. Finally, by taking Gansu as an example, it points out the deficiencies in the aspect of scientific and technological innovation, and also puts forward corresponding countermeasures and suggestions.
\end{abstract}

Keywords-Technological Innovation; Scientific and technological innovation; Innovative Capability Evaluation

\section{INTRODUCTION}

Regional scientific and technological innovation capacity is an important scale to measure the conditions of regional innovative system and an important means to reinforce the regional competitiveness and promote economic development. The increase of one region's scientific and technological innovation capacity has gradually become a decisive factor to obtain competitiveness.

"Decision of the CCCPC on Some Major Issues Concerning Comprehensively Deepening the Reform" puts forward the strategic thought of "Two Belts and One Road", which brings unprecedented his torical development opportunity for Gansu. To accelerate the progress of new industrialization, agricultural modernization and new urbanization, realize great-leap-forward development and the strategic objective of long-term peace and order, it must give full play to the huge promotion of science and technology and improve the regional scientific and technological innovation capacity.

\section{RESEARCH METHODS}

\section{A. Principal Component Analysis (PCA)}

In actual research, people are often encountered by multi-index (variable). Moreover, in most cases, there is certain correlation among different indicators, which will absolutely increase the complexity of problem analysis. PCA tries to recombine the previous indicators into a new group of comprehensive and irrelevant indicators to replace the original indicators. Meanwhile, it should select a few comprehensive indicators according to the actual demand, so as to try to reflect the information of original indicators as much as possible. Because the PCA can concentrate the information and simplify the structure of indicator, it makes the process of analyzing problem to be simple, intuitive and effective, thus it has been widely applied in all fields.

\section{B. Cluster Analysis Method}

Cluster Analysis, also called as group analysis and point group analysis, is a multi-statistic analysis applied in classification. According to several observation indicators of one batch of samples, it specifically finds out some statistics measuring the similarity degree between the samples or indicators, and then takes these statistics as the basis to classify the type. It integrates samples (or indicators) with great similarity into one classification and integrates other samples (or indicators) with great similarity into another classification. It will be completed until all samples (or indicators) are integrated. In Cluster Analysis, it is usually divided into Q cluster analys is and $\mathrm{R}$ cluster analysis according to the different objects of classification.

\section{ANALYSIS PROCESS}

\section{A. Construction of Scientific and Technological Innovation Capacity Indicator System}

While evaluating the innovation capacity of one region, it is quite important to select evaluation indicators. On the basis of systematicness, comprehensiveness, effectiveness and availability of data, this paper selects indicators to construct the scientific and technological innovation capacity indicator system, as shown in Table 1. 
TABLE I. TECHNOLOGICAL INNOVATION ABILITY EVALUATION SYSTEM

\begin{tabular}{|c|c|c|c|}
\hline $\begin{array}{c}\text { Targ } \\
\text { et } \\
\text { layer }\end{array}$ & $\begin{array}{l}\text { Guide } \\
\text { lines } \\
\text { layer }\end{array}$ & Index layer & Variable \\
\hline \multirow{20}{*}{$\begin{array}{l}\text { Scien } \\
\text { tific } \\
\text { and } \\
\text { techn } \\
\text { ologi } \\
\text { cal } \\
\text { innov } \\
\text { ation }\end{array}$} & \multirow{5}{*}{$\begin{array}{l}\text { Scien } \\
\text { ce } \\
\text { and } \\
\text { techn } \\
\text { ology } \\
\text { invest } \\
\text { ment }\end{array}$} & $\begin{array}{c}\text { Scientific and technological } \\
\text { activities }\end{array}$ & W1 \\
\hline & & $\begin{array}{l}\text { R \& D personnel equivalent to } \\
\text { full-time equivalents }\end{array}$ & W2 \\
\hline & & $\begin{array}{c}\text { R \& D internal expenses } \\
\text { (million) }\end{array}$ & W3 \\
\hline & & $\begin{array}{c}\text { expenditure as a percentage of } \\
\text { GDP } \%\end{array}$ & W4 \\
\hline & & $\begin{array}{l}\text { New Product Development } \\
\text { Expenditure }\end{array}$ & W5 \\
\hline & \multirow{6}{*}{$\begin{array}{c}\text { Tech } \\
\text { nolog } \\
y \\
\text { Innov } \\
\text { ation } \\
\text { Envir } \\
\text { onme } \\
\text { nt }\end{array}$} & $\begin{array}{c}\text { Every } 10 \text { million people have } \\
\text { the number of students in } \\
\text { Colleges and Universities }\end{array}$ & W6 \\
\hline & & Post and telecommunications & W7 \\
\hline & & Passenger turnover & W8 \\
\hline & & New urban fixed assets & W9 \\
\hline & & Gross Regional Product & $\mathrm{W} 10$ \\
\hline & & $\begin{array}{c}\text { HOUSEHOLD } \\
\text { CONSUMPTION }\end{array}$ & W11 \\
\hline & \multirow{4}{*}{$\begin{array}{c}\text { Tech } \\
\text { nolog } \\
y \\
\text { outpu } \\
t \\
\text { capac } \\
\text { ity }\end{array}$} & Patent Granted & $\mathrm{W} 12$ \\
\hline & & $\begin{array}{l}\text { The number of invention } \\
\text { patents }\end{array}$ & W13 \\
\hline & & Value of new products & W14 \\
\hline & & $\begin{array}{l}\text { Technology Market Turnover } \\
\text { (million) }\end{array}$ & W 15 \\
\hline & \multirow{5}{*}{$\begin{array}{c}\text { Enter } \\
\text { prise } \\
\text { innov } \\
\text { ation } \\
\text { abilit } \\
\text { y }\end{array}$} & LMEs $R$ \& D staff FTE & W16 \\
\hline & & $\begin{array}{c}\text { Large and medium industrial } \\
\text { enterprises in R \& D } \\
\text { expenditure (million) }\end{array}$ & W17 \\
\hline & & $\begin{array}{l}\text { LMEs number of items new } \\
\text { products }\end{array}$ & W 18 \\
\hline & & LMEs patent case & W19 \\
\hline & & $\begin{array}{c}\text { LMEs Value of new products } \\
\text { (million) }\end{array}$ & W20 \\
\hline
\end{tabular}

\section{B. Source of Sample Data}

According to the regional scientific and technological innovation capacity indicator system constructed above, it selects 30 provinces, districts and provinces in China mainland as the sample, except Hong Kong, Taiwan, Macao and Tibet (because the data of Tibet is incomplete, it cannot make the homogeneous comparis on, thus it is not listed as the evaluation object). Based on the relevant data of scientific and technological activities in 2008, it studies scientific and technological innovation capacity. Data in this paper mainly comes from "China Statistical Yearbook on Science and Technology in 2009", "China Statistical Yearbook in 2009" and "China Statistical Yearbook on Hitech Industry in 2009”.

\section{Analysis Process}

According to the principle of Factor Analysis Method, it applies the statistic software SPSS 16.0 to calculate corresponding characteristic value, contribution rate and accumulative contribution rate of all factors, and also component matrix after orthogonal rotation of all index variables, as shown in Table 2 and 3.

TABLE II. $\quad$ EIGENVALUES AND CUMULATIVE CONTRIBUTION RATE

\begin{tabular}{|c|c|c|c|c|c|c|}
\hline \multirow[b]{2}{*}{$\begin{array}{c}\text { Ing } \\
\text { red } \\
\text { ien } \\
t\end{array}$} & \multicolumn{3}{|c|}{ Initial eigenvalues } & \multicolumn{3}{|c|}{$\begin{array}{c}\text { Extracting square and } \\
\text { load }\end{array}$} \\
\hline & Total & $\begin{array}{c}\text { Varia } \\
\text { nce } \\
\text { contri } \\
\text { butio } \\
\text { n }\end{array}$ & $\begin{array}{l}\text { Accu } \\
\text { mulat } \\
\text { ion } \%\end{array}$ & Total & $\begin{array}{l}\text { Varia } \\
\text { nce } \\
\text { contri } \\
\text { butio } \\
\text { n }\end{array}$ & $\begin{array}{l}\text { Accu } \\
\text { mulat } \\
\text { ion } \%\end{array}$ \\
\hline 1 & $\begin{array}{c}12.30 \\
3\end{array}$ & $\begin{array}{c}61.56 \\
4\end{array}$ & $\begin{array}{c}61.56 \\
4\end{array}$ & $\begin{array}{c}12.30 \\
3\end{array}$ & $\begin{array}{c}61.56 \\
4\end{array}$ & $\begin{array}{c}61.56 \\
4\end{array}$ \\
\hline 2 & 4.584 & $\begin{array}{c}22.91 \\
8\end{array}$ & $\begin{array}{c}84.48 \\
3\end{array}$ & 4.584 & $\begin{array}{c}22.91 \\
8\end{array}$ & $\begin{array}{c}84.48 \\
3\end{array}$ \\
\hline 3 & 1.187 & 5.934 & $\begin{array}{c}90.41 \\
7\end{array}$ & 1.187 & 5.934 & $\begin{array}{c}90.41 \\
7\end{array}$ \\
\hline 4 & 0.991 & 4.955 & $\begin{array}{c}95.37 \\
2\end{array}$ & & & \\
\hline 5 & 0.265 & 1.324 & $\begin{array}{c}96.69 \\
6\end{array}$ & & & \\
\hline 6 & 0.217 & 1.086 & $\begin{array}{c}97.78 \\
3\end{array}$ & & & \\
\hline 7 & 0.135 & 0.677 & $\begin{array}{c}98.45 \\
9\end{array}$ & & & \\
\hline 8 & 0.088 & 0.440 & $\begin{array}{c}98.90 \\
0\end{array}$ & & & \\
\hline 9 & 0.069 & 0.343 & $\begin{array}{c}99.23 \\
4\end{array}$ & & & \\
\hline 10 & 0.045 & 0.224 & $\begin{array}{c}99.46 \\
7\end{array}$ & & & \\
\hline 11 & 0.036 & 0.179 & $\begin{array}{c}99.64 \\
7\end{array}$ & & & \\
\hline 12 & 0.019 & 0.096 & $\begin{array}{c}99.74 \\
3\end{array}$ & & & \\
\hline 13 & 0.016 & 0.081 & $\begin{array}{c}99.83 \\
2\end{array}$ & & & \\
\hline 14 & 0.014 & 0.068 & $\begin{array}{c}99.89 \\
1\end{array}$ & & & \\
\hline 15 & 0.010 & 0.049 & $\begin{array}{c}99.94 \\
0\end{array}$ & & & \\
\hline 16 & 0.007 & 0.036 & $\begin{array}{c}99.96 \\
7\end{array}$ & & & \\
\hline 17 & 0.002 & 0.012 & $\begin{array}{c}99.98 \\
8\end{array}$ & & & \\
\hline 18 & 0.001 & 0.006 & $\begin{array}{c}99.99 \\
4\end{array}$ & & & \\
\hline 19 & 0.001 & 0.004 & $\begin{array}{c}99.99 \\
9\end{array}$ & & & \\
\hline 20 & 0.000 & 0.001 & $\begin{array}{c}100.0 \\
0\end{array}$ & & & \\
\hline
\end{tabular}

From Table 2, it can be concluded that characteristic values of the first, second and third component are respectively $12.303,4.584$ and 1.187 , which are all larger than 1. Moreover, the accumulative contribution rate of variance achieves to $90.417 \%$, larger than $85 \%$, which concentrates most information of orig inal data. Therefore, 
it can extract the first three components as the principal component indicators to evaluate the regional scientific and technological innovative competitiveness. It takes the corresponding feature vectors of these three characteristic values as the new comprehensive indicators and then evaluates scientific and technological innovation capacity of 30 provinces, districts and cities in China mainland.

Economic significance of principal components is up to the comprehensive significance of several original indicators with quite large coefficient (absolute value) in the linear combination. From Table 3, it can be seen that, of the first principal components, the new product's development expenditure, quantity of patent application and grant, new product's output value, full-time equivalent of medium and large industrial enterprises' R\&D personnel, R\&D expenditure of medium and large industrial enterprises, quantity of medium and large industrial enterprises' new products, quantity of medium and large industrial industries' patent application and new product's output value have quite large loading coefficient, which mainly reflects the technological innovative capacity of enterprises. Thus it is called as the factor of technological innovative capacity of enterprises. Of the second principal components, the internal expenditure of $\mathrm{R} \& \mathrm{D}, \mathrm{R} \& \mathrm{D}$ expenditure's proportion of GDP, college students per 100000 people, GDP, household consumption level and technical market's turnover have quite large loading coefficient, which mainly reflects the expenditure of scientific and technological activities. Thus it is called as factor of scientific and technological input. Of the third principal components, the turnover of passenger traffic and urban newly-added fixed assets have quite large loading coefficient, which mainly reflects the influence of environment for scientific \& technological innovation on the innovative capacity. Thus it is called as factor of environment for scientific \& technological innovation.

TABLE III. LOAD FACTOR MATRIX

\begin{tabular}{|c|c|c|c|}
\hline Element & 1 & 2 & 3 \\
\hline $\begin{array}{c}\text { Scientific and technological } \\
\text { activities }\end{array}$ & 0.895 & -0.264 & $0 . \overline{-}$ \\
\hline $\begin{array}{l}\mathrm{R} \& \mathrm{D} \text { personnel equivalent } \\
\text { to full-time equivalents }\end{array}$ & 0.852 & -0.282 & $0 . \overline{-}$ \\
\hline $\begin{array}{c}\mathrm{R} \& \mathrm{D} \text { internal expenses } \\
\text { (million) }\end{array}$ & 0.394 & 0.818 & 0.271 \\
\hline $\begin{array}{c}\text { expenditure as a percentage } \\
\text { of GDP } \%\end{array}$ & 0.180 & 0.857 & 0.219 \\
\hline $\begin{array}{c}\text { New Product Development } \\
\text { Expenditure }\end{array}$ & 0.926 & -0.216 & $\begin{array}{c}- \\
0.233\end{array}$ \\
\hline $\begin{array}{l}\text { Every } 10 \text { million people } \\
\text { have the number of students } \\
\text { in Colleges and Universities }\end{array}$ & 0.375 & 0.861 & 0.089 \\
\hline $\begin{array}{c}\text { Post and } \\
\text { telecommunications }\end{array}$ & 0.918 & -0.288 & 0.004 \\
\hline
\end{tabular}

\begin{tabular}{|c|c|c|c|}
\hline Passenger turnover & 0.599 & -0.498 & 0.534 \\
\hline New urban fixed assets & 0.674 & -0.274 & 0.592 \\
\hline Gross Regional Product & 0.619 & 0.628 & $0 . \overline{137}$ \\
\hline $\begin{array}{l}\text { HOUSEHOLD } \\
\text { CONSUMPTION }\end{array}$ & 0.628 & 0.608 & 0.239 \\
\hline Patent Granted & 0.939 & -0.126 & $0 . \overline{-}$ \\
\hline $\begin{array}{c}\text { The number of invention } \\
\text { patents }\end{array}$ & 0.911 & 0.345 & $\begin{array}{c}- \\
0.103\end{array}$ \\
\hline Value of new products & 0.939 & 0.093 & $0 . \overline{2} 20$ \\
\hline $\begin{array}{l}\text { Technology Market } \\
\text { Turnover (million) }\end{array}$ & 0.445 & 0.844 & 0.071 \\
\hline LMEs R \& D staff FTE & 0.934 & -0.315 & 0.087 \\
\hline $\begin{array}{l}\text { Large and medium } \\
\text { industrial enterprises in } \mathrm{R} \\
\text { \& D expenditure (million) }\end{array}$ & 0.922 & -0.226 & 0.113 \\
\hline $\begin{array}{c}\text { LMEs number of items new } \\
\text { products }\end{array}$ & 0.936 & -0.013 & 0.251 \\
\hline LMEs patent case & 0.933 & -0.250 & $0 . \overline{158}$ \\
\hline $\begin{array}{l}\text { LMEs Value of new } \\
\text { products (million) }\end{array}$ & 0.952 & -0.063 & 0.007 \\
\hline
\end{tabular}

After determining the principal components, by applying SPSS20, it can conclude the scores of 30 provinces, cities and districts of China main land in each principal component. And then with the help of Excel, it takes the proportion of each principal component's variance contribution ratio to three principal components' contribution ratio as the weight, and applies the weighted summarization to get each region's comprehensive score of innovation capacity, as shown in Table 4. Because the contribution ratio of the first principal component does not surpass $85 \%$, if it only sorts by the score of the first principal component, there is not enough information, which will be unilateral. Therefore, with the help of SPSS 20 , it fatherly makes cluster analysis on the scores of selected first, second and third principal components. This cluster analysis adopts the hierarchical clustering process, the Ward as the clustering method adopts and the Squared euclidean distance as the distance measure and finally gets the hierarchical diagram of systematic cluster analysis, as shown in Fig. 1. 


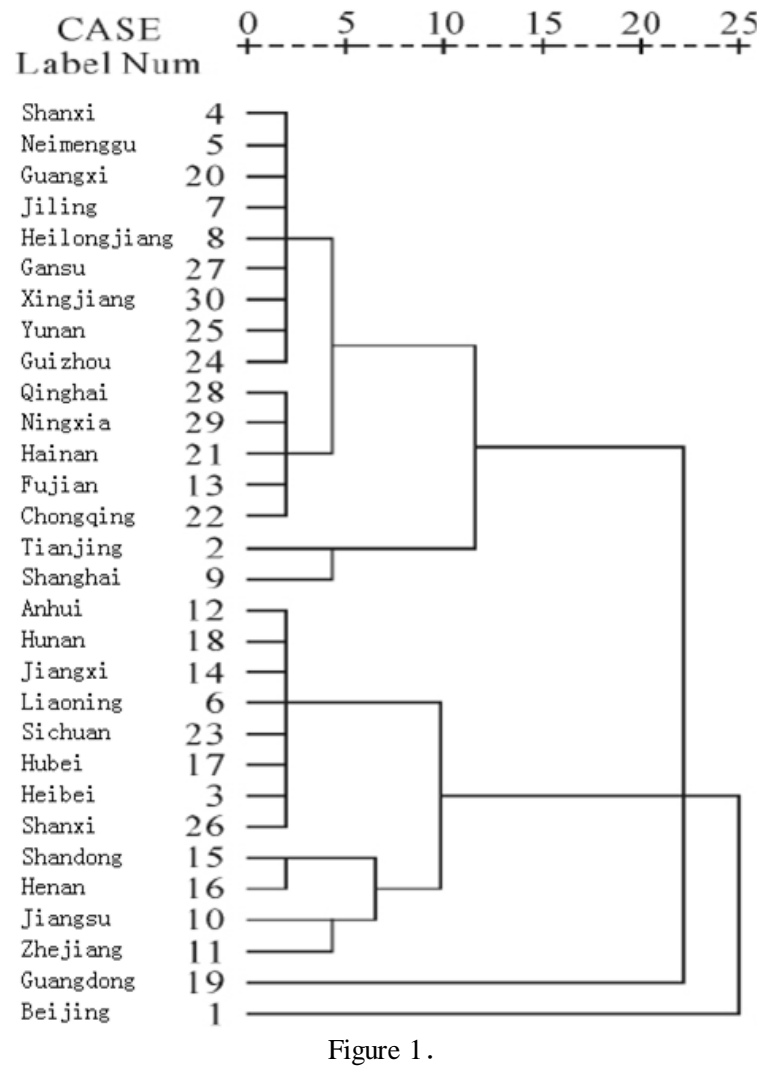

\section{RESULT ANALYSIS}

According to the cluster analysis dendrogram and comprehensive score of principal components (as shown in Table 4), based on the strength and weakness of regional innovation capacity, it roughly divides 30 provinces, cities and districts of China mainland to six classifications. Classification 1: Beijing; Classification 2: Guangdong; Classification 3: Shanghai, Tianjin; Classification 4: Jiangsu, Shandong, Zhejiang, Henan; Classification 5: Liaoning, Sichuan, Shanxi, Hubei, Hebei, Hunan, Anhui, Jiangxi; Classification 6: Fujian, Heilongjiang, Jilin, Chongqing, Shanxi, Inner Mongolia, Guangxi, Gansu, Yunnan, Xinjiang, Hainan, Guizhou, Ningxia, Qinghai.

\section{A. Analysis on Each Classification}

Classification 1: as the capital, Beijing is the political, economic and cultural center of the whole nation, which integrates the most abundant innovation resources. Due to the developed economy, convenient transportation and high degree of opening up to the outside world, no matter in the aspect of environment for science and technology and technological innovation capacity of enterprises, or in the aspect of science and technology input, Beijing takes the leading position in China. Thus it has the strongest scientific and technological innovation capacity.

Classification 2: Guangdong is the cutting-edge window of China's reform and opening up to the outside world. Adjacent to Hong Kong, Macao and Taiwan, it has superior geographical conditions, active commodity economy, strong economic base and enterprise's innovation capacity. However, there is still a certain gap between Guangdong and Beijing in the aspect of input in environment for science and technology and science and technology activities. Thus Guangdong comes second to
Beijing in the aspect of scientific and technological innovation capacity.

Classification 3: As municipalities directly under the central government, Shanghai and Tianjin are extra-large cities and well-known ports in China. The enterprises' innovation capacity of these two cities respectively rank 6th and 8th, the scientific and technological input respectively rank 2nd and 3rd. In the aspect of patent application quantity, new product's output value, full-time equivalent of medium and large industrial enterprises' R\&D personnel, R\&D expenditure, quantity of new product item, regional household consumption level and colleges and universities, Shanghai and Tianjin both top the list in China. Thus they rank Classification 3.

Classification 4: Among Jiangsu, Shandong, Zhejiang and Henan, in the aspect of the most important 1st factor-enterprise's innovation capacity, Jiangsu comes second to Guangdong, ranking 2nd in China, Shandong follows closely, ranking 3rd. Zhejiang and Henan respectively rank 5th and 9th. Although these four provinces are in the same classification, it can clearly see that, there is an obvious gap among these four cities in the aspect of innovation capacity. Of which, enterprises of Jiangsu have the strongest innovation capacity, with the highest comprehensive score. Therefore, Jiangsu ranks the 1st in this classification. The comprehensive score of Shandong and Zhejiang are 0.71 and 0.66 respectively; with no big difference, ranking 2nd and 3rd. Henan is the only province in the central region of China. Compared to the previous three provinces, no matter in the aspect of enterprise's innovation capacity or science and technology input, there is a large gap, ranking lowest in the same classification. The factor of location mainly contributes to that. Jiangsu, Zhejiang and Shandong all belong to eastern coastal areas, with solid industrial base, developed commodity economy, superior geological location and convenient land and water communication. But Henan is located in central plain, which has not too many advantages to utilize. In the aspect of turnover of passenger traffic and urban newly-added fixed assets, Henan ranks the top, which are a little bit higher than those of other three provinces. It makes up for its deficiencies in other two aspects to a certain extent, thus it is also included in Classification 4.

Classification 5: from the above analysis, we can see that, of the 8 provinces and cities in previous four classifications, they all belong to eastern areas except Henan; but of 8 areas in Classification 5, only Liaoning and Hebei belong to eastern areas, the rest belong to central and western regions. In the aspect of enterprise's innovation capacity, that of Liaoning and Sichuan are positive values, that of the rest 6 provinces and cities are negative values, which are obviously lower than the national average. Of which, scores of Liaoning in the as pect of three principal components are all higher than the national average, ranking 1st. Sichuan and Shanxi only have one item below the average. In the aspect of enterprise's technological innovation capacity, the more important 1st factor, Sichuan is higher than that of Shanxi. Thus Shanxi comes second to Sichuan, respectively ranking 2nd and 3rd. The other ranking is Hubei, Hebei, Hunan, Anhui and Jiangxi in sequence. In this classification, the 3rd factor --turnover of passenger traffic 
and urban newly-added fixed assets of these regions are all higher than the national average, which shows that these 8 regions have quite strong scientific and technological potential and possibly enter the previous 4 classifications after improving some regional deficiencies.

Classification 6: there are 14 provinces, cities and districts, including 2 eastern provinces (Fujian and Hainan), 3 central provinces (Heilongjiang, Jilin and Shan xi) and 9 western provinces, cities and districts (Chongqing, Inner Mongolia, Guangxi, Gansu, Yunnan, Xinjiang, Guizhou, Ning xia and Qinghai). As these 14 regions, their scientific and technological innovation capacity are all negative values, which are below the national average, most of them have not achieved the average level in scientific technological input and innovative environment.

It makes analysis on the regional ranking. Eastern areas Beijing, Guangdong, Shanghai, Tianjin, Jiangsu, Shandong, Zhejiang, Liaoning, Hebei, Fujian and Hainan. Middle areas: Henan, Hubei, Hunan, Anhui, Jiang xi, Heilongjiang, Jilin and Shanxi. Western areas: Sichuan, Shanxi, Chongqing, Inner Mongolia, Guang xi, Guizhou, Gansu, Yunnan, Xinjiang, Ningxia, Qinghai.

\section{B. From the above ranking, it can be concluded that}

Development of scientific and technological innovation capacity are unbalanced, with obvious regional differences Generally, the eastern part is the strongest, the central part is in the middle and the western part is poorest. In addition, all regions have great differences internally. For instance, eastern Fujian and Hainan belong to the 6th classification, but Beijing and Guangdong belong to 1st and 2nd classification. The eastern and western areas have similar problems as well;

Enterprise's innovation capacity is the most important factor of one region's scientific and technological innovation capacity. If enterprises have strong innovation capacity, the region's scientific and technological innovation capacity will be correspondingly strong and vice versa. Enterprise innovation capability of Henan and Sichuan respectively rank top in central and western areas, and their comprehensive rankings are the strongest in central and western areas. Enterprise innovation capacity of Hainan, Guang xi and Qinghai is the poorest in eastern, central and western areas, so is the comprehensive ranking. It shows that the principal status of enterprise innovation has been gradually reinforced, which is consistent with the result concluded by the principal component analysis. To a certain extent, it shows that this analys is is reasonable.

It analyzes the scientific and technological capacity of Gansu, which ranks 24 th among 30 provinces, cities and districts in China, ranks 6th among 11 western provinces and 3rd among 5 northwest provinces. No matter in China, western areas or northwestern areas, the scientific and technological capacity of Gansu is at the lower level. There is a large gap between Gansu and advanced areas. Undoubtedly, such a gap originates from influence of science and technology input and innovative environment. However, the most important reason is that the enterprises' technological innovation capacity is too poor (ranking 24th in China). Of indicators affecting the enterprise's technological innovation capacity, Gansu has no advantages in the following aspects: full-time equivalent of medium and large industrial enterprises' $R \& D$ personnel, R\&D expenditure, and quantity of new product item, quantity of patent application and output value of new product.

\section{COUNTERMEASURES AND SUGGESTIONS}

In order to improve the scientific and technological innovation capacity of Gansu, shorten its gap with developed areas and realize the great-leap-forward development of Gansu, this paper puts forward suggestions from 3 principal factors affecting regional scientific and technological innovation capacity:

In the aspect of improving the enterprise's technological innovation capacity, it must strengthen the principal status of enterprises. Scientific and technological input and output of medium and large-scale enterprises in Gansu lag far behind those of developed provinces in eastern areas. The government must create a good innovative environment, guide and support enterprises to increase the input in innovation through fiscal, taxation and police levels. More importantly, enterprises should strengthen the science technology and information communication, improve the quality of scientific research personnel, and increase the innovative efficiency and scientific technological output, so as to really enable enterprises to play the role of promoting the local science technology innovation.

In the aspect of science technology input, enterprises need to strengthen communication and cooperation with local colleges and scientific research institutions, increase scientific and technological R\&D personnel, increase research funds and improve the conversion rate of scientific and technological input, promote the effective industry-university-research integration.

In the aspect of improving the scientific and technological innovative environment, the government should improve the infrastructure, accelerate the pace of constructing informatization, create good environment, spare no efforts to attract foreign investments, positively expand foreign trades, and strengthen communication and cooperation outside Gansu.

\section{CONCLUSIONS}

Regional technological innovation capacity is an important factor to affect the local economy, especially the industrial economy and hi-tech industry, and the core and impetus for regional economic development. By the integration of principal component analysis and cluster analysis, it evaluates the scientific and technological innovation capacity of 30 provinces, cities and districts in China mainland. Conclusion of this paper basically conforms to the reality, which shows it is reasonable and feasible to apply such a method to evaluate the multiindicator variable problem. The deficiency of this paper lies in that, while constructing the evaluation indicator system, it just selects quantitative indicators, but neglects the influence of qualitative indicators on the regional scientific and technological innovation capacity. Thus it needs to be improved.

\section{REFERENCES}

[1] Baer, M. and M. Frese., 2003. Innovation Is Not Enough: Climates for Initiative and Psychological Safety, Process Innovations, and Firm Performance, Journal of Organizat ional Behavior, 24(1), 4568. 
[2] Biggart, N.W. and Hamilton, G., 1992. On the limits of a firmbased theory to explain business networks: The Western bias of neoclassical economics, In Nohria, N. and Eccles, R. (Eds.), Networks and Organizations: Structure, Form and Action Cambridge, 471-490, Ma: Harvard, Business School Press.

[3] Bryson, J.R. and Monnoyer, M.C., 2004. Understanding the relationship between services and innovation: the RESER review of the European service literature on innovation, The Service Industries Journal, 24(1), 205-22.

[4] Chau, P. Y. K. and Lai, V. S. K., 2003. An empirical investigation of the determinants of user acceptance of Internet banking, Journal of Organizational Computing and Electronic Commerce, 13(2), 123-145.

[5] Clemens, B. and Douglas, T. J., 2006. Does coercion drive to adopt "voluntary" green initiatives? Relationships among coercion, superior firm resources, and volunt ary green initiatives, Journal of business Research, 59, 83-491.

[6] Coombs, R. and Miles, I., 2000. Innovation, measurement and services, in Metcalfe, J. S. and Miles, I. (Eds.), Innovation Systems in the Service Economy, Measurement and Case study Analysis, Kluwer Academic, Bost on, MA, 85-103.

[7] Damanpour, F. and Evan, W. M., 1984. Organizational Innovation and Performance: The problem of organizational lag, Administrative Science Quarterly, 29, 392-409.

[8] Didier, B. V. and Sylvie, G., 2002., Impact of social innovation on company 3 performance: an empirical study of highinvolvement practices, Measuring Business Excellence.

[9] DiMaggio, P. J. and Powell, W. W., 1983. The iron cage revisited: Institutional isomorphism and collective rationality in organizational fields, American Sociological Review, 48, 147-160.

[10] Drejer, I., 2004. Identifying innovation in surveys of services: a schumpeterian perspective, Research Policy, 33(3), 551-562.

[11] Edwards, C. and Peppard, J. W., 1994. Business process redesign: hype, hope or hypocrisy? Journal of Information Technology, 9, 251-266.

[12] Eguiluz, V. M., Zimmermann, M. G., Cela-Conde, C. J. and San, M., 2005. Cooperation and the emergence of role differentiation in the dynamics of social networks, American Journal of Sociology, 110(4), $977-1008$

[13] Guler, I., Guillen, M. F., and Macpherson, J. M., 2002. Global competition, institutions, and the diffusion of organizational practices: The international spread of ISO 9000 quality certificates, Administrative Science Quarterly, 47(2), 207-232.

[14] Gustafsson, A. and Michael, D. J., 2004. Determining Attribute Importance in a Service Satisfaction Model, Journal of Service Research, 7(2), 124-141

[15] Hamilton, G. G. and Biggart, N. W., 1988. Market, culture and authority: A comparative analy sis of management and organization in the far east, American Journal of Sociology, 94, 52-94.
[16] Hamilton, G. G. and Nicole W. B., 1991. The organization of business in Taiwan: A reply to Numazaki, American Journal of Sociology, 96(4), 999 .

[17] Han, J. K., Kim, N. and Srivastava, R. K., 1998. Market orientation and organizational performance: Is innovation a missing link? Journal of Marketing, 62(4), 30-45.

[18] Hannan, M. T. and Freeman, J., 1989. Organizational Ecology, Cambridge, Massachusetts, Harvard University Press.

[19] Haunschild, P. R. and Miner, A. S., 1997. Modes of interorganizational imitation: The effects of outcome salience and uncertainty, Administrative Science Quarterly, 42(3), 472-500.

[20] Haveman, Heather A., 1993. Organizational size and change: Diversification in the savings and loan industry after deregulation, Administrative Science Quarterly, 38, 20-50.

[21] Hayward, M. L. A., 2002. When Do Firrns Learn frorn Their Acqui sition Experience? Evidence from 1990-1995, Strategic Management Journal, 23(1), 21-39.

[22] Hess, M., 2004. Spatial' relationships? Towards a reconceptualization of embeddedness, Progress in Human Geography, $28(2), 165-186$

[23] Kalakota, R. and Marcia, R. 1999. E-Business: roadmap for success, Addison Wesley Longman, Inc.

[24] Korsching, P. F. and El-Ghamrini, S., 2003. Rural Telephone Company Adoption of Service Innovations: A Community Field Theory Approach, Rural Sociology, 68(3), 387.

[25] Kotler, P., 2003. Marketing management, New Jersey: Prentice Hall.

[26] Lenox, M. and A. King., 2004. Prospects for Developing Absorpti ve Capacity through Internal Information Provi sion, Strategic Management Journal, 25(4), 331-345.

[27] Magnusson, D., 2003. The person approach: Concepts, measurement models, and research strategy, Special Issue of New Directions for Child and Adolescent Development, 101, 3-23.

[28] Mahoney, J., 2001. Beyond Correlational Analysis: Recent Innovations in Theory and Method, Sociological Forum, Review Essay, 16(3), 575-593.

[29] Mahoney, J., 2010. After KKV The New Methodology of Qualitative Research, Review Articles, World Politics, 62(1), 120147.

[30] Melão, N. and Pidd, M., 2000. A Conceptual framework for Understanding Business Processes and Business Processes Modelling, Information Systems Journal, 10(2), 105-129.

[31] Minford, P. and Peel, D., 2002. Advanced Macroeconomics: A Primer, Chs, 2-4, Cheltenham: Edward Elgar.

[32] Palmer, D. A., Jennings, P. D. and Zhou, A., 1993. Late adoption of the multidivisional form by large U.S. corporations: Institutional political and economic accounts, Administrative Science Quarterly, 38, 100-131. 